\section{Clinical and laboratory features of children and adolescents with congenital hypothyroidism due to dyshormonogenesis in southern Brazil}

\author{
Características clínicas e laboratoriais de crianças \\ e adolescentes com hipotireoidismo congênito \\ devido a disormonogênese no sul do Brasil
}

Juliana Cristina Romero Rojas Ramos', Luiz de Lacerda Filho', Adriane de André Cardoso DeMartini', Rodrigo Bruel da Silveira', Rosana Marques Pereira' ${ }^{1}$, Romolo Sandrini Neto', Suzana Nesi França'

\begin{abstract}
Objective: To characterize the phenotype of patients with congenital hypothyroidism ( $\mathrm{CH}$ ) due to dyshormonogenesis, and to hypothesize on the degree of genetic defect. Subjects and methods: Patients with dyshormonogenesis were subdivided into G1 (radioactive iodine uptake, RAIU > 15\%; $n=62$ ) and G2 (RAIU $\leq 15 \% ; n=32$ ). Thyroglobulin (TG) was measured in all patients; perchlorate discharge test (PDT) was performed in G1; and saliva-to-plasma radioiodine ratio (I- S/P) in G2. Results: Levels of TSH, $\mathrm{TT}_{4^{\prime}}$ and $\mathrm{FT}_{4}$ before treatment and upon diagnosis confirmation were significantly different in both groups, but not between groups. In G1, 27 patients developed goiter; 17 had positive PDT (14\%-71\% discharge), 11 had TG $<2.5 \mathrm{ng} / \mathrm{dL}$ (one with high TSH), and one developed thyroid carcinoma. In G2, four patients developed goiter, and three had low I- S/P. Conclusion: These data suggest an iodide organification defect in 17 cases; an iodide transport defect (NIS defect) in three, probable TSH resistance in 10, and a TG synthesis defect in two cases. Arq Bras Endocrinol Metab. 2012;56(3):201-8
\end{abstract}

\section{Keywords}

Congenital hypothyroidism; thyroid hormones; goiter; thyroglobulin

\section{RESUMO}

Objetivo: Caracterizar o fenótipo de pacientes com hipotireoidismo congênito (HC) por disormonogênese e sugerir o nível do defeito genético. Sujeitos e métodos: Pacientes com disormonogênese foram subdivididos em G1 (captação de ${ }^{131}$ I $>15 \% ; n=62$ ) e G2 (captação $\leq 15 \% ; n=$ 32). Tireoglobulina (TG) foi dosada em todos, teste de descarga do perclorato (TDP) foi realizado no G1 e relação iodo salivar/sérico (I- S/P), no G2. Resultados: Os valores de $T S H, T_{4} T_{\text {e }} T_{4} L$ pré-tratamento e na confirmação do diagnóstico foram significativamente diferentes em ambos os grupos ( $p<0,01)$, mas não entre eles. No G1, 27 pacientes desenvolveram bócio; TDP foi positivo em 17 (descarga de 14\%-71\%); 11 tiveram TG <2,5 ng/dL (um com TSH elevado) e um desenvolveu carcinoma de tireoide. No G2, quatro pacientes desenvolveram bócio e três apresentaram baixa I-S/P. Conclusão: Esses dados sugerem defeito na organificação do iodeto em 17 casos; defeito no transporte do iodeto (defeito na NIS) em três, provável resistência aoTSH em 10 e defeito na síntese deTG em dois. Arq Bras Endocrinol Metab. 2012;56(3):201-8

\section{Descritores}

Hipotireoidismo congênito; hormônios tireoidianos, bócio; tireoglobulina
Unidade de Endocrinologia Pediátrica, Departamento de Pediatria, Hospital de Clínicas, Universidade Federal do Paraná (HC-UFPR), Curitiba, PR, Brazil

Correspondence to: Suzana Nesi França Rua Padre Camargo, 250 80060-240 - Curitiba, PR, Brazil snesifranca@hotmail.com

Received on 28/Aug/2011 Accepted on 14/Feb/2012 


\section{INTRODUCTION}

$\mathrm{C}$ ongenital hypothyroidism $(\mathrm{CH})$ is the most common congenital endocrine disease and a preventable cause of mental retardation. The disorder is permanent and results primarily from abnormalities in the development of the thyroid, either dysgenesis or agenesis. The second most common cause of $\mathrm{CH}$ is dyshormonogenesis, i.e., inborn errors of thyroid hormone synthesis. Other less frequent etiologies include defects in the binding of thyroid-stimulating hormone (TSH) to its receptor, and pituitary or hypothalamic abnormalities, such as central and secondary or tertiary hypothyroidism.

Recent advances in molecular biology have led to better understanding of the steps involved in thyroid hormone synthesis, and the genes involved in this process. Several genes have been identified and mutations have been recognized as causes of $\mathrm{CH}(1,2)$. Dyshormonogenesis is usually transmitted in an autosomal recessive pattern (3). Clinical manifestations of $\mathrm{CH}$ caused by dyshormonogenesis are similar to those associated with thyroid dysgenesis, except for a familial incidence and a tendency to develop goiter during the neonatal period or, more commonly, during childhood or adulthood. In order to identify the etiology of the dyshormonogenesis, additional investigation is required, and includes the perchlorate discharge test (PDT), measurement of serum thyroglobulin (TG), iodide saliva-to-plasma ratio (I- S/P) and molecular genetic analysis. The latter test is not easily available in daily practice.

About $10 \%$ to $15 \%$ of the newborns with $\mathrm{CH}$ are affected by dyshormonogenesis. However, due to a decrease in the TSH cutoff values in neonatal screening to 12 or $10 \mathrm{mU} / \mathrm{L}$ over the last years, more cases of $\mathrm{CH}$ have been detected, mainly caused by milder defects in thyroid hormone synthesis (4). Dyshormonogenesis may occur due to defects in any level of synthesis or secretion of thyroid hormones, such as iodide transport, iodide organification, synthesis of TG, and iodotyrosine deiodination. The most common defect affects thyroperoxidase (TPO) activity, leading to abnormalities in iodide oxidation and organification, and interfering with its binding to the tyrosine molecule (2).

To date, few studies have characterized the phenotype of a large group of patients with thyroid dyshormonogenesis. The aim of this study was to assess the clinical and laboratory features of children and adolescents with $\mathrm{CH}$ due to dyshormonogenesis, and to investigate whether the identification of these features could suggest the degree of genetic defect that culminated with dyshormonogenesis.

\section{SUBJECTS AND METHODS}

Between June 1991 and May 2008, the Neonatal Screening Program of the state of Paraná identified 759 patients with elevated TSH, and referred these patients to the Pediatric Endocrinology Unit of Federal University of Paraná (UEP-UFPR) for additional evaluation. From 407 patients with a diagnosis of permanent CH, 108 (26,6\%) had an in situ thyroid with normal morphology on scintigraphy, compatible with dyshormonogenesis. Fourteen patients were excluded for being followed up at another service, interrupting treatment for more than six months, or presenting a concomitant genetic syndrome. The final cohort consisted of 94 patients, of whom 54 (57\%) were female.

Initial clinical and laboratory data were retrieved from medical records, and information collected before treatment and at the time of the confirmation of $\mathrm{CH}$ diagnosis was included. These data included levels of TSH, total $\mathrm{T}_{4}$ (TT4), free $\mathrm{T}_{4}$ (FT4) and 24hour ${ }^{131} \mathrm{I}$ radioactive iodine uptake (RAIU). Random serum TSH and TG were obtained in all patients. According to the RAIU, patients were divided into two groups. Group l (Gl) was made up of patients with RAIU greater than $15 \%$, and group $2(\mathrm{G} 2)$ of those with RAIU lower than or equal to $15 \%$. Patients categorized as Gl underwent further evaluation with PDT, whereas those categorized as G2 had salivary and plasma iodine measured for assessment of the serum-to-plasma iodine ratio (I- S/P).

Blood samples for measurement of TSH, $\mathrm{TT}_{4}$ and $\mathrm{FT}_{4}$ were collected in the morning of the visit, before the administration of levothyroxine $\left(\mathrm{L}-\mathrm{T}_{4}\right)$, or in the

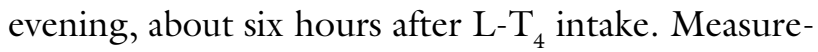
ments were performed at the Clinical Analysis Laboratory of the UFPR School Hospital. $\mathrm{TT}_{4}, \mathrm{FT}_{4}$, and TSH were measured using Immulite $2000^{\circledR}$ Analyzer (DPC) by chemiluminescence, with analytical sensitivity of $0.3 \mu \mathrm{g} / \mathrm{dL}, 0.18 \mathrm{ng} / \mathrm{dL}$, and $0.002 \mathrm{mU} / \mathrm{L}$, respectively. Serum TG was also measured by chemiluminescence (reference value 2 to $60 \mathrm{ng} / \mathrm{mL}$ ). 
Thyroid scan, PDT and salivary iodide measurement were performed at the Nuclear Medicine Service of the UFPR School Hospital. Thyroid scan was performed between 2.5 and 3 years of age. In preparation for the scan, $\mathrm{L}-\mathrm{T}_{4}$ was suspended for 30 days. Patients received a dose of $50 \mu \mathrm{Ci}$ of ${ }^{131} \mathrm{I}\left({ }^{123} \mathrm{I}\right.$ is not available in our institution) followed by RAIU measurement at 24 hours. In 11 patients, the scan was performed using ${ }^{99 \mathrm{~m}} \mathrm{Tc}$ due to a temporary shortage of radioiodine. Uptake was then considered normal or high based on the visual aspect.

In preparation for PDT, $\mathrm{L}_{-} \mathrm{T}_{4}$ was suspended for 30 days. For the test, patients received potassium perchlorate at a dose of $10 \mathrm{mg} / \mathrm{kg}$ body weight after administration of ${ }^{131} \mathrm{I}$. Due to a limited availability of potassium perchlorate capsules, the test was not performed in all Gl patients and priority was given to patients with normal or high TG levels. When patients had iodide discharge between $10 \%$ and $90 \%$, they were considered to have a partial iodide organification defect (PIOD), and when discharge was above $90 \%$, total iodide organification defect (TIOD) (5).

I- $\mathrm{S} / \mathrm{P}$ was calculated by measuring the radioactivity of $1 \mathrm{~mL}$ of saliva and $1 \mathrm{~mL}$ of blood aliquots collected after an oral radioiodine dose of $500 \mu \mathrm{Ci}$. The test was considered normal when the plasma-to-saliva iodide ratio was above 25 , whereas values close to 1 indicated a complete iodide trapping defect. A I S $/ \mathrm{P}$ ratio of up to 20 represented partial defects (6).

At UEP-UFPR, thyroid ultrasound is performed routinely in patients with $\mathrm{CH}$. However, the exam is performed by different examiners at random ages. As, in this cohort, the exam was performed at different ages, with different degrees of laboratorial control, and by different examiners, thyroid volume ultrasound measurements were not used as a parameter in this study.

Informed consent was obtained from all patients in accordance with the guidelines of the Ethical Committee of the Federal University of Paraná School Hospital.

Statistical analyses were performed using the software Statistica (Statsoft, version 7.1). For all analyses, nonparametric Mann-Whitney test for betweengroup comparisons was applied, and a minimum level of $5 \%$ was considered significant $(\mathrm{p}<0.05)$.

\section{RESULTS}

Overall, median age at first evaluation was 25.5 days (range: 4 to 88 days).

\section{Description of G1}

Gl was made up of 62 patients $(65.9 \%)$. All subjects in this group had a normal or enlarged thyroid on scintigraphy. The scan was performed with radioactive iodine in 51 patients of this group, whereas in $11,{ }^{99 \mathrm{~m}} \mathrm{Tc}$ was used, resulting in normal or increased uptake. Most patients in this group were female $(\mathrm{n}=38 ; 61.2 \%)$. Median age at first evaluation was 26.5 days (range: 4 to 88 days). Six patients had consanguineous parents, and in four of these cases (two siblings), parents were first-degree cousins. Goiter was absent in all children at the initial visit and developed during follow-up in 27 of them. Other prevalent clinical signs were umbilical hernia (48\%), abdominal distension (42\%), prolonged jaundice $(38.7 \%)$, depressed nasal bridge (30.6\%), large posterior fontanel (22.5\%), hoarse cry, and constipation (both 19.3\%).

As shown in table 1 , there were significant differences on $\mathrm{TSH}, \mathrm{TT}_{4}$, and $\mathrm{FT}_{4}$ levels measured before treatment and upon diagnosis confirmation $(\mathrm{p}<0.01)$.

Random serum TG ranged from 0.5 to $168 \mathrm{ng} /$ $\mathrm{mL}$ (mean $27.2 \mathrm{ng} / \mathrm{mL}$, standard deviation 37.8 $\mathrm{ng} / \mathrm{mL}$; median $11.3 \mathrm{ng} / \mathrm{mL}$ ). As shown in table 2, eleven patients had TG below $2.5 \mathrm{ng} / \mathrm{mL}$, and only one of these patients had an elevated TSH (10.2 $\mathrm{mU} / \mathrm{L})$. Eight patients had TG levels above $60 \mathrm{ng} /$ $\mathrm{mL}$, three of them with normal TSH.

PDT was performed in 30 patients $(46.8 \%)$. The test was normal in 13 cases, whereas in 17 , it was considered positive with an iodide discharge ranging from $14 \%$ to $71 \%$, compatible with PIOD. Among patients with positive PDT, nine had goiter $(53 \%)$. There were no significant differences in iodide discharge values among patients with and without goiter $(\mathrm{p}=0.38)$. The three patients shown in table 2 who presented high TG with normal TSH levels had goiter and positive PDT.

Median pretreatment TSH levels were lower in patients with normal PDT compared with those with positive PDT (75.0 mU/L versus $100.0 \mathrm{mU} / \mathrm{L}$, respectively; $\mathrm{p}=0.03)$. However, there were no differences in TSH levels between these two groups when measured upon diagnosis confirmation $(14.5 \mathrm{mU} /$ $\mathrm{mL}$ versus $28.8 \mathrm{mU} / \mathrm{mL}$, respectively; $\mathrm{p}=0.10)$, and during PDT (15.1 mU/mL versus $23.0 \mathrm{mU} / \mathrm{mL}$, respectively; $\mathrm{p}=0.64$ ).

One patient in this group developed a follicular variant of papillary carcinoma at the age of 15 years. 
Throughout follow-up, mean serum TSH in this patient was $1.54 \mathrm{mU} / \mathrm{L}$ (range 0.02 to $4.71 \mathrm{mU} / \mathrm{L}$ ). Goiter was observed at the age of seven, which developed together with the thyroid nodule, in spite of the fact that TSH levels remained within the normal range.

\section{Description of G2}

G2 was made up of 32 patients with normal thyroid morphology and RAIU less than $15 \%$. Half of the patients $(\mathrm{n}=16)$ were male. Median age at first evaluation was 21.5 days (range 11 to 80 days). Only one patient in this group had consanguineous parents (first-degree cousins). At initial evaluation, goiter was present in only one child, whereas the most prevalent clinical signs were umbilical hernia, abdominal distension and prolonged jaundice (50\%), depressed nasal bridge $(43.7 \%)$, and hoarse cry $(40.6 \%)$.

Table 1 shows the levels of $\mathrm{TSH}, \mathrm{TT}_{4}$, and $\mathrm{FT}_{4}$ measured before treatment and upon diagnosis confirmation in this group. There was a significant difference in $\mathrm{TSH}$ and $\mathrm{TT}_{4}$ levels (both $\mathrm{p}<0.01$ ), but not in $\mathrm{FT}_{4}(\mathrm{p}=0.8 \mathrm{l})$ measured before treatment and upon diagnosis confirmation.

Serum TG levels ranged from 0.5 to $460 \mathrm{ng} / \mathrm{mL}$ (mean $45.9 \mathrm{ng} / \mathrm{mL}$, standard deviation $90.6 \mathrm{ng} / \mathrm{mL}$; median $13.5 \mathrm{ng} / \mathrm{mL}$ ). Four patients had TG below $2.5 \mathrm{ng} / \mathrm{mL}$ but normal TSH, whereas six patients had high TG associated with high TSH, except for one patient in whom TSH was not available (Table 2).

I- S/P was calculated in 13 patients. Low I- S/P was found in three of them (Table 3 ). None of these patients had consanguineous parents and only one showed goiter on the first evaluation ( 21 days) that persisted throughout childhood.
Table 2. Serum $T G(n g / m L)$ and $T S H(m U / L)$ in patients of $G 1$ and $G 2$

\begin{tabular}{|c|c|c|}
\hline Patient & $\mathrm{TG}(\mathrm{ng} / \mathrm{mL})$ & $\mathrm{TSH}(\mathrm{mU} / \mathrm{mL})$ \\
\hline \multicolumn{3}{|l|}{ G1 } \\
\hline 8 & 0.5 & 1.70 \\
\hline 18 & 0.5 & 2.70 \\
\hline $19^{(1)}$ & 0.5 & 10.20 \\
\hline 22 & 0.5 & 1.25 \\
\hline 35 & 0.5 & 3.46 \\
\hline 39 & 0.5 & 2.54 \\
\hline 48 & 1.6 & 4.10 \\
\hline 49 & 0.5 & 1.27 \\
\hline 56 & 1.6 & 2.24 \\
\hline 58 & 0.5 & 0.34 \\
\hline 62 & 1.3 & 0.42 \\
\hline 9 & 162.0 & Not available \\
\hline 17 & 74.4 & 6.58 \\
\hline $21^{(2)}$ & 129.0 & 2.57 \\
\hline 25 & 112.0 & 5.72 \\
\hline 36 & 81.5 & 100.00 \\
\hline $45^{(2)}$ & 81.3 & 3.90 \\
\hline $50^{(2)}$ & 168.0 & 3.30 \\
\hline 57 & 64.1 & 7.91 \\
\hline \multicolumn{3}{|l|}{ G2 } \\
\hline 4 & 1.7 & 1.13 \\
\hline 17 & 0.5 & 3.46 \\
\hline 29 & 0.5 & 1.49 \\
\hline 30 & 0.9 & 0.90 \\
\hline 7 & 71.9 & Not available \\
\hline 11 & 77.5 & 8.31 \\
\hline 15 & 164.0 & 15.40 \\
\hline 21 & 93.1 & 8.61 \\
\hline 31 & 460.0 & 100.00 \\
\hline 32 & 230.0 & 17.10 \\
\hline
\end{tabular}

(1) Patient with low TG and high TSH; (2) Patients with high TG and normal TSH.

Table 1. Serum levels of $\mathrm{TSH}_{1} \mathrm{TT}_{4}$, and $\mathrm{FT}_{4}$ in $\mathrm{G} 1$ and $\mathrm{G} 2$ patients measured before treatment and upon diagnosis confirmation

\begin{tabular}{|c|c|c|c|c|c|c|}
\hline Parameter & G1 - Pretreatment & $\begin{array}{l}\text { G1 - Diagnosis } \\
\text { confirmation }\end{array}$ & $p$-value & G2 - Pretreatment & $\begin{array}{c}\text { G2 - Diagnosis } \\
\text { confirmation }\end{array}$ & p-value \\
\hline Median TSH (mU/L) & $\begin{array}{c}75.00 \pm 161.70 \\
(25.20-813)^{(a)} \\
(n=62)\end{array}$ & $\begin{array}{c}35.70 \pm 78.58 \\
(7.18-472)^{(\mathrm{b})} \\
(\mathrm{n}=62)\end{array}$ & $<0.01$ & $\begin{array}{c}107.46 \pm 208.73 \\
(8.7-822)^{(a)} \\
(n=32)\end{array}$ & $\begin{array}{c}30.04 \pm 77.68 \\
(6.11-331)^{(\mathrm{b})} \\
(\mathrm{n}=32)\end{array}$ & $<0.01$ \\
\hline Median $T_{4}(\mathrm{ng} / \mathrm{dL})$ & $\begin{array}{c}2.33 \pm 3.38 \\
(0.06-15.50)^{(c)} \\
(n=61)\end{array}$ & $\begin{array}{c}6.58 \pm 3.02 \\
(1.00-12.40)^{(\mathrm{d})} \\
(n=58)\end{array}$ & $<0.01$ & $\begin{array}{c}2.35 \pm 3.53 \\
(0.09-13.40)^{(\mathrm{c})} \\
(n=32)\end{array}$ & $\begin{array}{c}5.55 \pm 3.89 \\
(0.35-11.97)^{(\mathrm{d})} \\
(n=28)\end{array}$ & $<0.01$ \\
\hline Median $\mathrm{FT}_{4}(\mu \mathrm{g} / \mathrm{dL})$ & $\begin{array}{c}0.35 \pm 0.44 \\
(0.01-1.95)^{(e)} \\
(n=22)\end{array}$ & $\begin{array}{c}0.93 \pm 0.35 \\
(0.20-1.56)^{(1)} \\
(n=34)\end{array}$ & $<0.01$ & $\begin{array}{c}0.40 \pm 0.63 \\
(0.01-1.66)^{(e)} \\
(n=5)\end{array}$ & $\begin{array}{c}0.51 \pm 0.44 \\
(0.20-1.36)^{(1)} \\
(n=17)\end{array}$ & 0.81 \\
\hline
\end{tabular}

Comparison between G1 and G2: (a) pretreatment TSH: $p=0.31$; (b) diagnosis confirmation TSH: $p=0.95$; (c) pretreatment $\Pi_{4}: p=0.42$; (d) diagnosis confirmation $T_{4}: p=0.13 ;$ (e) pretreatment $\mathrm{FT}_{4}: \mathrm{p}=0.85 ;(f)$ diagnosis confirmation $\mathrm{F}_{4}: \mathrm{p}=0.05$. 
Table 3. Laboratory characteristics of G2 patients with low I-S/P

\begin{tabular}{cccccc}
\hline Patient & $\begin{array}{c}\text { Pretreatment } \\
\text { TSH (mU/mL) }\end{array}$ & $\begin{array}{c}\text { Diagnosis } \\
\text { confirmation } \\
\text { TSH (mU/L) }\end{array}$ & $\begin{array}{c}\text { RAIU } \\
\text { (\%) }\end{array}$ & $\begin{array}{c}\text { Serum } \\
\text { TG } \\
\text { (ng/dL) }\end{array}$ & I- S/P \\
\hline 2 & 312 & 7.1 & 3.7 & 28 & 13 \\
5 & 280 & 31.8 & 13.6 & 31 & 4.9 \\
$27^{(1)}$ & 60 & 75 & 1.3 & 5.7 & 1.3 \\
\hline
\end{tabular}

(1) Patient with goiter.

Goiter was observed in four patients: $\mathrm{I}^{-} \mathrm{S} / \mathrm{P}$ was normal in one of them, low in another one, and it was not calculated in the other two patients.

\section{Comparison between G1 and G2}

Compared with G1, G2 patients were more likely to have some of the clinical manifestations of $\mathrm{CH}$ in the first evaluation, such as hoarse cry and pallor $(\mathrm{p}=$ $0.03)$, hypotonia and ocular hypertelorism $(\mathrm{p}=0.01)$, as well as hypoactivity $(\mathrm{p}<0.01)$. Statistical analysis showed no significant difference between Gl and G2 in relation to TSH levels measured before treatment and upon diagnosis confirmation. However, $\mathrm{FT}_{4}$ levels upon diagnosis confirmation were higher in G1 than in G2, with borderline significance ( $\mathrm{p}=$ $0.05)$, as shown in table 1 .

\section{DISCUSSION}

We found a prevalence of dyshormonogenesis equal to $26.6 \%$ among patients screened for $\mathrm{CH}$ by the Neonatal Screening Program of the State of Paraná. These patients were subsequently followed up at the UEP-UFPR. This prevalence was higher than the one classically described in the literature, which is about $15 \%$. However, more recent studies have shown increased incidence of $\mathrm{CH}$ and higher prevalence of milder forms of dyshormonogenesis due to lower cutoff values of TSH in the screening for the disease $(4,7)$.

Because of the lack of a reference values for RAIU in the pediatric population, we chose a cutoff value of $15 \%$ for patient classification, based on reports showing RAIU of up to $15 \%$ in patients with congenital I' transport defects (10).

Several patients were older than 30 days at the first visit. This reflects deficiencies in the Screening Program during the first years of its implementation. The area of coverage of the Brazilian National Screening Program varies among states. Coverage in the southern region of the country, where Paraná is located, is $87.1 \%$, the best national average. The state of Paraná has a coverage rate of $88 \%$, according to a 2008 report, and the average age at the onset of treatment in this state is 15 days $(8,9)$.

Overall, $57 \%$ of the patients were female, similar to other reports in the literature that show similar sex distribution for dyshormonogenesis, unlike thyroid dysgenesis which shows higher prevalence in females, with a ratio of $2: 1(2)$.

Unfortunately not all patients underwent all tests. If available, molecular study would have added more information and enabled further conclusions about this population. So far, we understand that patients with dyshormonogenesis present wide phenotypic variability, which limits the definition of the etiology based only on clinical and laboratory data. The type of the genetic defect may be related to some prognostic features, such as goiter development, neurological outcome, hearing loss, and even thyroid cancer. This knowledge will be of great importance for a more specific clinical follow-up, and for familial counseling.

Before treatment, G2 patients had higher levels of TSH than those in Gl, although this difference was not statistically significant. There was no significant difference between the groups in relation to TSH levels measured upon diagnosis confirmation, but levels of $\mathrm{FT}_{4}$ measured at this moment were higher in G1 than in G2. Furthermore, some signs and symptoms of hypothyroidism described at first evaluation were more frequent in G2, suggesting that patients with impaired I- uptake, probably as a result of NIS mutations or TSH resistance, have more severe hypothyroidism.

In both groups, pretreatment levels of $\mathrm{TSH}$ and $\mathrm{TT}_{4}$ were significantly higher and lower, respectively, when compared with levels found upon diagnosis confirmation. Lower $\mathrm{TT}_{4}$ at birth suggests that hypothyroidism may be more severe at birth, and that thyroid function may recover at least partially with age.

As for TG values, it was not possible to consider all results, since in most patients, TSH levels were normal. Low TG level associated with high TSH was found only in one patient in whom a TG synthesis defect was suspected, although no goiter development has been observed yet. This patient had a pretreatment TSH level of $325 \mathrm{mU} / \mathrm{L}$, RAIU of $30.5 \%$, and normal PDT. Absence of synthesis and secretion of TG was confirmed by absence of an increment in 
serum TG (serum TG $0.8 \mathrm{ng} / \mathrm{dL}$ ) in a sample collected during PDT with maximum TSH stimulation $(\mathrm{TSH}>100 \mathrm{mU} / \mathrm{L})$. The parents of this child are first degree cousins and the brother also has $\mathrm{CH}$. Interestingly, the phenotype of the brother is slightly different: he presented a pretreatment TSH level of $75 \mathrm{mU} / \mathrm{L}$, high ${ }^{99 \mathrm{~m}} \mathrm{Tc}$ uptake, normal PDT, goiter, and serum TG in the lower limit, which did not increase with high TSH stimulation, either. Defective TG synthesis usually results in goitrous $\mathrm{CH}$ (11-13). Nevertheless, it would be interesting in both cases to search for mutations in the TG gene.

There were three patients (patients 21, 45 and 50) who had high serum TG and normal TSH, all of them with goiter and positive PDT (iodide discharge of 58\%, $71 \%$ and $55 \%$, respectively), compatible with PIOD.

Unfortunately PDT was performed in only $58 \%$ of the patients in Gl, because of the limited availability of potassium perchlorate capsules. All positive PDT results were compatible with PIOD. Among these 17 patients, only nine had goiter $(53 \%)$, a lower incidence compared with $70 \%$ (49 out of 71 ) reported by Cavarzere and cols. (14). This discrepancy may be related to geographic, ethnic and molecular differences, number of patients evaluated, or even to the fact that, in our study, the presence of goiter was considered based only on physical examination, whereas in the study of Cavarzere and cols., goiter was defined based on scintigraphic data.

There was no difference between the results of PDT in patients with and without goiter, reflecting no tendency in patients with higher iodide discharge to develop goiter. Similarly, there was no correlation between the presence of goiter and levels of TSH measured before treatment or upon diagnosis confirmation. This observation is different from the report of Cavarzere and cols., who described significantly higher TSH levels in patients with goiter (14). This difference was probably due to the lower number of patients in our study (17 patients versus 71 ) and to the reasons mentioned above.

The wide phenotypic variation among patients with PIOD, also reported by Cavarzere and cols. (14), is linked to the diversity of genetic disorders. PIODs are more commonly associated with TPO gene mutations (about $50 \%$ of cases), especially when goiter is present $(15,16)$. Therefore, PIOD may also be caused by mutations in other genes that encode proteins associated with any of the steps involved with iodide organification. In the 17 patients with PIOD in our study, the genetic etiology of the defect has not been defined yet. However, in 9 of these patients who presented goiter, the hypothesis of a TPO mutation is reasonable. Another possible etiology to be considered is Pendred syndrome. Patients with $\mathrm{CH}$ at UEP-UFPR are now referred to hearing screening, which will probably help to direct the search for an etiological diagnosis. However, since both Pendred syndrome and defects in TPO may be present with goiter, hypothyroidism and positive PDT, no definitive etiologic diagnosis is possible without molecular evaluation of patients who show concomitant hearing loss.

Tonacchera and cols. described a patient with $\mathrm{CH}$ and no goiter who was followed up until 14 years of age. This patient had mildly elevated TSH $(32 \mathrm{mU} / \mathrm{L}$ on diagnosis, and $6 \mathrm{mU} / \mathrm{L}$ after six weeks of treatment), normal serum TG and a 13\% iodide discharge at PDT. The authors found, in this patient, two novel mutations in DUOX2, which were responsible for the PIOD. This finding showed that inactivating mutations of DUOX2 may be responsible for PIOD-related mild cases of $\mathrm{CH}$ (17). In our study, three subjects had clinical and laboratory features similar to this patient.

Although we had no cases compatible with TIOD, this diagnosis is still possible in our cohort, considering that there are still 20 patients in Gl in whom we intend to perform PDT.

PDT was normal in 14 patients and in six of them, goiter was present. All these patients, except for one, had normal TG with normal or slightly elevated TSH. In half of them, TSH-stimulated TG was measured during PDT, and in all of these patients, TG levels were high, reflecting its ability to accumulate in the colloid, since its synthesis is not impaired. The identification of the degree of molecular defect in these patients based on their clinical and laboratory characteristics is challenging: normal or high RAIU, normal or elevated serum TG, normal PDT, and goiter. Considering patients with normal PDT, the main hypothesis for them would be TG defects, since serum levels may vary from undetectable to normal or even high, in these cases. However, patients with TG defects typically present congenital large goiter. Pendred syndrome is a possible diagnosis in this scenario, since it typically presents positive PDT, although there have been reports of patients with normal PDT and SLC26A4 mutation (18). Hearing screening would be important in these patients. Other diagnoses to consider are defects in iodotyrosine deiodinase, as 
they have been described in association with mild cases of hypothyroidism with goiter (19).

RAIU below or equal to $15 \%$ is highly suggestive of iodide transport defects (NIS defects). The clinical characteristics of patients with NIS mutations include goiter, in most cases, and hypothyroidism in variable degrees, usually related to iodine intake.

The diagnosis of iodide transport defects is based on I- S/P. In our study, goiter was observed in only four patients who had wide variation in laboratory parameters. Only two of these patients underwent salivary iodine measurement, and only one had a low I- $\mathrm{S} / \mathrm{P}$, confirming a defect in NIS protein. Two other patients, described in table 3 , had low I S/P. It would be of particular interest to have molecular analysis of NIS in order to define the genetic defect in these patients. In the other subjects with low RAIU and normal I- S/P, we suspect the occurrence of TSH resistance. Iodine contamination, which frequently interferes with thyroid scan, was not considered, since iodine intake in our region is within the established parameters for iodine sufficiency (20).

More than ten cases of thyroid cancer in patients with goiter and dyshormonogenesis have been described in the literature. Prolonged stimulation by high levels of TSH may play a role in the development of the goiter and/or tumor progression, since all cases have been reported in patients with elevated TSH and long-term inadequate treatment (2l). Most cases reported are related to defects in TG synthesis, in one case a mutation was found in the PDS gene and in another, in the TPO gene (22). Recently, Raef and cols. described the first case of a metastatic follicular variant of papillary carcinoma associated with a p.R2223H TG gene mutation (23). One of our patients also presented a follicular variant of papillary carcinoma, but had no signs of metastases. Also, unlike all cases described, this patient had always maintained normal TSH levels, contradicting the hypothesis that the development of the tumor could be influenced by elevated TSH. It would be of great importance to search for a $T G$ mutation in this patient and to analyze possible mutations in oncogenes and tumor suppressor genes.

\section{CONCLUSION}

Patients with $\mathrm{CH}$ due to dyshormonogenesis presented wide phenotypic variability, limiting the de- finition of the etiology based only on clinical and laboratory information. However, a suggestion of etiological diagnosis was possible in 32 patients: 17 with iodide organification defect, three patients with iodide transport defect, 10 patients with probable TSH resistance, and two patients with probable TG synthesis defect.

Acknowledgements: we would like to thank Dr. Luiz Carlos Wollner, as well as the nurses and technicians of the Nuclear Medicine Service of the UFPR School Hospital for their contribution in the exams; Dr. Helton Estrela Ramos for helping with the PDT test; Dr. Monica Nunes Lima for her kind help in the statistical analysis; the staff at the UEP-UFPR for the assistance to the patients and their families, and to the Research Center of the Ecumenical Foundation of Protection for the Handicapped for the Neonatal Screening Program.

Disclosure: no potential conflict of interest relevant to this article was reported.

\section{REFERENCES}

1. Park SM, Chatterjee VKK. Genetics of congenital hypothyroidism. J Med Genet. 2005;42(5):379-89.

2. Fisher DA, Grueter A. Disorders of the thyroid in the newborn and infant. In: Sperling MA, editors. Pediatric Endocrinology. 3.ed. Philadelphia:W.B. Saunders; 2008. p. 198-226.

3. LaFranchi S. Congenital hypothyroidism: etiologies, diagnosis, and management. Thyroid. 2009;9(7):735-40.

4. Corbetta C, Weber G, Cortinovis F, Calebiro D, Passoni A, Vigone $\mathrm{MC}$, et al. A 7-year experience with low blood TSH cutoff levels for neonatal screening reveals an unsuspected frequency of congenital hypothyroidism (CH). Clin Endocrinol. 2009;71(5):739-45.

5. Bakker B, Bikker H, Vulsma T, De Randamie JS, Wiedijk BM, De Vijlder JJ. Two decades of screening for congenital hypothyroidism in The Netherlands: TPO gene mutations in total iodide organification defects (an update). J Clin Endocrinol Metab. 2000;85(10):3708-12.

6. Pohlenz J, Refetoff S. Mutations in the sodium/iodide symporter (NIS) gene as a cause for iodide transport defects and congenital hypothyroidism. Biochimie. 1999;81:469-76.

7. Harris KB, Pass KA. Increase in congenital hypothyroidism in New York State and in the United States. Mol Genet Metab. 2007;91(3):268-77.

8. Ministério da Saúde. Disponível em: http://portal.saude.gov.br. Acesso em: Mar 28, 2011.

9. Vargas PR. Exposição de centros de referências regionais - Região Sul. In: Medeiros-Neto G, Knobel M, editores. Hipotireoidismo congênito no Brasil: desafios à busca de soluções. São Paulo: Conectfarma Publicações Científicas; 2008. p. 107-9.

10. Medeiros-Neto G, Stanbury JB. The iodide transport defect. In: Medeiros-Neto G, Stanbury JB, editores. Inherited Disorders of the Thyroid System. Boca Raton: CRC Press; 1994. p. 37-52.

11. Hishinuma A, Takamatsu J, Ohyama $Y$, Yokozawa $T$, Kanno $Y$, Kuma K, et al. Two novel cysteine substitutions (C1263R and C1995S) of thyroglobulin cause a defect in intracellular transport of thyroglobulin in patients with congenital goiter and the variant type of adenomatous goiter. J Clin Endocrinol Metab. 1999;84(4):1438-44. 
12. Pardo V, Rubio IG, Knobel M, Aguiar-Oliveira MH, Santos MM, Gomes SA, et al. Phenotypic variation among four family members with congenital hypothyroidism caused by two distinct thyroglobulin gene mutations. Thyroid. 2008;18(7):783-6.

13. Caputo M, Rivolta CM, Esperante SA, Gruñeiro-Papendieck L, Chiesa A, Pellizas CG, et al. Congenital hypothyroidism with goiter caused by new mutations in the thyroglobulin gene. Clinical Endocrinol. 2007;67:351-7.

14. Cavarzere P, Castanet M, Polak M, Raux-Demay MC, Cabrol S, Carel JC, et al. Clinical description of infants with congenital hypothyroidism and iodide organification defects. Horm Res. 2008;70:240-8.

15. Weber G, Vigone MC, Passoni A, Odoni M, Paesano PL, Dosio F, et al. Congenital hypothyroidism with gland in situ diagnostic re-evaluation. J Endocrinol Invest. 2005;28:516-22.

16. Avbelj M, Tahirovic H, Debeljak M, Kusekova M, Toromanovic A, Krzisnik C, et al. High prevalence of thyroid peroxidase gene mutations in patients with thyroid dyshormonogenesis. Eur J Endocrinol. 2007;156:511-9.

17. Tonacchera M, De Marco G, Agretti P, Montanelli L, Di Cosmo C, Freitas Ferreira $A C$, et al. Identification and functional studies of two new dual-oxidases 2 (DUOX2) mutations in a child with congenital hypothyroidism and eutopic normal-size thyroid gland. $\mathrm{J}$ Clin Endocrinol Metab. 2009;94(11):4309-14.
18. Reardon W, Omahoney CF, Trembath R, Jan H, Phelps PD. Enlarged vestibular aqueduct: a radiological marker of Pendred syndrome, and mutation of the PDS gene. Q J Med. 2000;93(2):99-104.

19. Moreno JC, KlootwijkW, Van Toor H, Pinto G, D'alessandro M, Lèger $A$, et al. Mutations in the iodotyrosine deiodinase gene and hypothyroidism. N Engl J Med. 2008;358:1811-8.

20. Marino MAZ, Martins LC, Esteves RZ, KasamatsuTS, Maciel RMB. Urinary iodine in patients with auto-immune thyroid disorders in Santo André, SP, is comparable to normal controls and has been steady for the last 10 years. Arq Bras Endocrinol Metab. 2009;53(1):55-63.

21. Medeiros-Neto G, Stanbury JB. Thyroid malignancy and dyshomonogenetic goiter. In: Medeiros-Neto G, Stanbury JB, editores. Inherited Disorders of the Thyroid System. Boca Raton: CRC Press; 1994. p. 207-18.

22. Alzahrani AS, Baitei EY, Zou M, ShiY. Metastatic follicular thyroid carcinoma arising from congenital goiter as a result of a novel splice donor site mutation in the thyroglobulin gene. J Clin Endocrinol Metab. 2006;91(3):740-6.

23. Raef H, Al-Rijjal R, Al-Shehri S, Zou M, Al-Mana H, Baitei EY, et al. Biallelic p.R2223H mutation in the thyroglobulin gene causes thyroglobulin retention and severe hypothyroidism with subsequent development of thyroid carcinoma. J Clin Endocrinol Metab. 2010;95(3):1000-6. 